\title{
鉄道駅周辺における小売店舗の立地動向及び業種分布に関する研究 RESEARCH ON TREND OF LOCATION AND DISTRIBUTION OF COMMERCIAL TYPE ABOUT SMALL SHOPS AROUND RAILWAY STATION
}

\author{
隋 洪 キン* , 趙 世 晨** \\ Hongxin SUI and Shichen ZHAO
}

\begin{abstract}
Recently, the potential value of railway stations is attached great importance again in cities. Research on development of integration station with urban area has being carried out. With the decreasing in surrounding shops, the purchasing of daily necessities is becoming more and more inconvenience, as well as the coming of the aging society. The central urban area such as the area around stations declines not only in outer suburbs but also in city centers. The shops of daily necessities and fresh food decrease sharply in shopping street. The railway station gathers commercial and business functions. In order to promote the formation of intensive urban area, the service convenience of station should be enhanced further. Selecting the small-scale railway stations in Fukuoka City as research objects, we studied the distribution situation, annual change of shops and commercial types, as well as their relationship with population and number of users. For promoting the station-central urban renewal and improvement of service convenience, we determined the location characteristics of shops and different commercial types, using the adjoint index of nearest distance. The conclusions of our research are as follows: 1) the number of shops showed a decreasing tendency with the passing of time; 2) the location of shops was closer to agglutination distribution; 3) the characteristic of commercial types distribution showed both gathering and dispersion tendency.
\end{abstract}

Keywords : Railway Station, Small Shops, Location Characteristic, Distribution of Commercial Type, Annual Change 鉄道駅，小売店舗，立地動向，業種分布，経年変化

\section{1. はじめに}

\section{1 研究の背景}

近年，人口減少，地球環境問題の高まり，厳しい財政的制約など, 都市を取り巻く社会経済情勢が変化している現状においては，都市 の無秩序な拡散を抑制し，都市機能の集積を促進する集約拠点とそ の他の地域を公共交通ネットワークで有機的に連携させる「集約型 都市構造」へ再編するとともに，にぎわいのあるコンパクトなまち づくりを目指した動きは全国の多くの自治体でみられる ${ }^{1)}$.とりわけ, 地方中枢都市においては, 鉄道駅のもつ潜在的なポテンシャルが見 直され，まちなか居住や，駅と一体となった市街地活性化の取り組 みが展開されている ${ }^{2)}$.

一方，身近な商店の減少，本格的高齢社会の到来は，日常的な買 い物に支障が「買い物弱者」を生み出している．特に近年，この問 題が各地で深刻になった背景には，過疎地だけではなく，地方中枢 都市などでも駅前などの中心市街地が衰退し，商店街で日常生活用 品や生鮮食品を扱う店舗が激減したと指摘されている ${ }^{3), ~ 1)}$. 鉄道駅 は古くからの商業・業務機能が集積し, 人々の生活や娛楽・交流の
場を形成している場合が多く，今後コンパクトな市街地の形成に向 けて，鉄道駅の利便性のさらなる向上は求められている.

\section{2 研究の目的と論文の構成}

上述の背景を踏まえながら, 本研究では, 日常生活に必要な商品 を手に入れる場として，福岡市の鉄道駅の中から都市中心の大・中 規模鉄道駅を除き，乗降数が 20,000 人 / 日以下の小規模鉄道駅（一 部乗降数 20,000 人〜 30,000 人 / 日の駅）を対象に，駅周辺地域に 立地する小売店舗とその業種の分布実態, 経年変化及び人口・乗降 数等との関係を把握し, 最近隣尺度と最近隣空間的随伴尺度の指標 を用いて，店舗及び業種別の立地パターンを明らかにして，今後， 駅を中心とするまちづくり及び買い物利便性の向上に一助となるこ とを目的とする.

本論文は 5 章で構成されている，第 1 章では，研究の背景，目的 および論文の構成について述べる．第 2 章では，調査対象駅の選定 と対象店舗及び業種構成について述べている．第 3 章では，調査対 象地域の店舗分布実態及び経年変化を把握するとともに，人口と乗 降者数との関係について考察し, 最近隣尺度を用いて, 駅周辺にお
* 九州大学大学院人間環境学府 博士後期課程

** 九州大学大学院人間環境学研究院 准教授・博士 (工学)
Doctor Candidate, Graduate School of Human-Environment Studies, Kyushu University Assoc. Prof., Faculty of Human-Environment Studies, Kyushu University, Dr. Eng. 
ける店舗の立地パターンを明らかにする. 第 4 章では, 対象地域の 業種ごとの店舗分布状況と経年変化を把握し, 最近隣空間的随伴尺 度を用いて, 業種間の店舗分布対応パターンを明らかにし, 業種分 布特性及び周辺人口との関係に述べている. 第 5 章では, 本論文の 内容, 分析結果を要約し, 考察を加えてまとめとしている.

\section{3 既往研究}

既往研究では，商業立地特性分析に関する研究は数多く行われて いる.まず，商業施設の立地に関わる制度・規制及びコントロール に関する研究では, 浅野氏 ${ }^{5)}$ は金沢市と長野市の事例比較から地方 中核都市における自治体独自の大規模商業施設立地調整方策の実態 と課題を明らかにしている. 小林氏ら ${ }^{6)}$ は線引き制度の運用に着目 し, 線引き都市, 非線引き都市それぞれの商業施設立地の特徵及び 消費・購買に与える影響を検討し, 線引き制度の運用は中心市街地 に商業施設を集積させ，既存商業の衰退を抑制する一定の効果があ ると指摘している. 姥浦氏ら ${ }^{7), 8)}$ は京都市及びドイッ・ドルトムン ト市を事例に自治体レベルにおける大規模小売店舗開発の立地コン トロールの運用実態, 公開と課題について考察を行っている.

1990 年代以降の大店法の規制緩和と共に, 大型商業施設の郊外開 発が地方中枢都市から地方中小都市に至るまで浸透し, 中心市街地 の衰退問題を引き起こしたといら社会的な背景に, 幹線道路沿道に 集積する商業施設の立地に関する一連の研究が発表されている. 浅 野氏ら ${ }^{9)}$ は長野県の未線引き用途無指定地域を対象にロードサイド に集積する商業施設の立地構造を分析し, その問題点, 改題を明ら かにしている. また, 大規模商業施設の中心市街地における閉店や 郊外移転の実態及びその後の利用の方向性に着目した研究も同氏に よるものである ${ }^{10)}$. さらに, 商業施設立地の沿道化及び立地移動に 着目した角谷氏 ${ }^{11}$, 山岸氏 ${ }^{12)}$ の研究がある. 木多氏ら ${ }^{13), 14)}$ は, ショッ ピングセンターを地域の核施設と位置づけ，その周辺における地域 施設発生の実態を時系列的に追跡調查し, その周辺の施設発生に及 ぼしている範囲や施設分布の空間的特性を明らかにしている.

一方, 鉄道駅周辺地域に着目し, 地域施設の分布特性及び発生の 予測手法に関する李氏ら ${ }^{15)}$, ${ }^{16)}$ の研究がある. 同氏らは, 鉄道駅周 辺に分布する教育施設, 公共・行政施設等を含む地域市民の日常利 用施設を地域施設と定義し, その分布実態と経年変化を明らかにし た上, 数量化 I 類を用いて施設発生に影響を及ぼしている要因を明 らかにするとともに, 数量化理論による予測方法の有効性を検討し ている.

本研究は, これらの既往研究の成果を踏まえて, 鉄道駅周辺地域 における日常買い物の利便性のさらなる向上と, そして鉄道駅を中 心としたコンパクトなまちづくりの推進に必要とされている商業施 設に関する基礎情報を提供するために，鉄道駅周辺地域に分布する 小売店舗に着目し, その立地動向及び業種分布の特性を明らかにし ようとするもので，これまでの研究にはない.

\section{2. 研究対象の概要}

\section{1 駅周辺環境の把握亡対象駅の選定}

まず, 福岡市内の鉄道駅の立地環境を把握するために, 福岡市内 で運行されている JR 九州は 5 路線（新幹線を除く）, 西日本鉄道は 2 路線, 福岡市営地下鉄は 3 路線, 計 10 路線の内, 乗降者数 20,000 人/日以下の 51 駅を対象 (図 1 に示寸) に, 駅周辺の土地利用構成,
人口分布数及び乗降者数のデータを用いて, クラスター分析を行っ た. なお, 本研究での鉄道駅周辺地域については, 徒歩圈内・駅勢 圈・幹線道路の位置・人口分布状況などを考慮し, さらに既往研究 $\left.{ }^{15)}, 16\right)$ を参考にして, 駅の主要改札口を中心に半径 $600 \mathrm{~m}$ の範囲に 設定した.

具体的には, 2010 年における各駅の乗降者数（出典 : 福岡市統 計書), 福岡市都市計画基䃈調查の土地利用データ, 福岡市住民基 本台帳の人口データを用いて, 各種データの標準化を行った上で, 対象間の平方ユークリッド距離に基づいて, ウォード法によるクラ スター分析を行った. なお, 土地利用データの算定方法については, 都市計画基䃈調查のデータをもとに, 表 1 に示す「商業」、住宅」、官 公庁・文教等」、「公園・緑地等」、「道路・河川等」、「他」の 6 つのカテゴリーにまとめ, 駅の主要改札口から半径 $600 \mathrm{~m}$ に全体及 び一部を含まれる全ての町丁目のデータを集計し, 各種土地利用面 積の構成比を算出した. また, 駅周辺人口の算定に関しては, 各町 丁目の人口が均一に分布すると仮定し，600m 圈内に含まれる面積 の割合で人口を比例配分して求めた.

クラスター分析の結果を表 1 に示すように，分析対象の 51 駅を 5 つのグループに分けることが出来た. 各グループの特徴は, 以下 に簡潔にまとめる.

グループ 1（17 駅）に関して，乗降者数及び「官公庁・文教等」 の土地利用構成比はほかのグループに比べて最も少なく，人口も全 グループの平均以下で,「住宅」は比較的多いことから,このグルー プは低密度居住地域に立地し，鉄道利用者の少ない地域であるとい える. グループ 2 (6 駅) に関しては, 駅周辺の人口は最も少なく, 「その他」都市的以外の土地利用は最も多いグループである.グルー プ 3 (6 駅) の土地利用構成比をみると, 「官公庁・文教等」34\%で, 他のグループに比べて突出して多い.これはこのグループの駅周辺 に大学等の教育施設が多く立地していることに起因すると考えられ る. グループ4（10 駅）に関しては, 駅周辺人口と「住宅」の土地 利用構成比は最も多いことから, 比較的高密度居住地域にあるのは 特徵であるといえる．グループ 5 (12 駅) の乗降者数,「商業」と「道

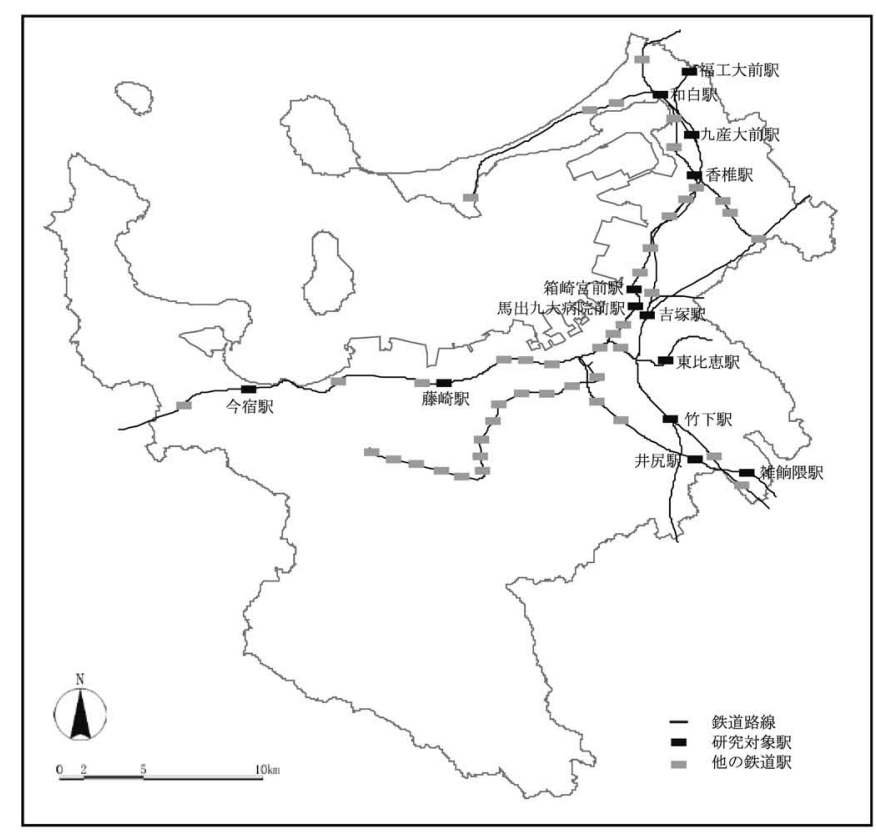

図 1 福岡市鉄道駅の位置 
路河川等」の土地構成比は高く,「住宅」は最も低いことから，こ のグループは都心あるいは近隣商業地域に立地する駅が多いと考え られる。

以上のように, 福岡市内に立地する乗降者数 20,000 人 / 日以下 の小規模鉄道駅を周辺環境の異なる 5 つのグループに分類すること が出来た.これは駅周辺における小売店舗の立地傾向と業種分布の 分析を行う際に, 対象駅選定のベースとなる.

\section{2 対象駅の選定}

駅周辺の土地利用状況, 人口分布及び駅の乗降者数によって, 小

表1 クラスター分析の結果

\begin{tabular}{|c|c|c|c|c|c|c|c|c|c|c|}
\hline \multirow{3}{*}{ クラスター } & \multirow{3}{*}{ 駅名 } & \multirow{3}{*}{ 路線 } & \multirow[b]{2}{*}{ 乗降数 } & \multirow{2}{*}{$\begin{array}{c}\text { 駅周辺 } \\
\text { 人口 }\end{array}$} & \multicolumn{6}{|c|}{ 土地利用カテゴリー } \\
\hline & & & & & 商業 & 住宅 & $\begin{array}{l}\text { 官公序 } \\
\text { 文教等 }\end{array}$ & $\begin{array}{l}\text { 公園 } \\
\text { 緑地等 }\end{array}$ & $\begin{array}{l}\text { 道路 } \\
\text { 河川等 }\end{array}$ & その他 \\
\hline & & & (人/日) & (人) & \multicolumn{6}{|c|}{$(\%)$} \\
\hline \multirow{18}{*}{$\begin{array}{l}\text { Group } 1 \\
\text { (17駅) }\end{array}$} & 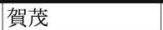 & 地下鉄 & 3,926 & 9,198 & 5.6 & 46.8 & 5.3 & 6.0 & 20.4 & 2.6 \\
\hline & 次郎丸 & 地下鉄 & 4,353 & 7,813 & 4.4 & 45.6 & 2.6 & 4.6 & 22.4 & 4.4 \\
\hline & 野芥 & 地下鉄 & 5,816 & 9,136 & 5.5 & 45.8 & 3.8 & 6.7 & 24.3 & 4.3 \\
\hline & 名島 & 西鉄 & 1,723 & 10,126 & 3.2 & 42.8 & 7.1 & 12.5 & 28.9 & 5.3 \\
\hline & 唐の原 & 西鉄 & 1,041 & 7,826 & 6.5 & 45.4 & 0.4 & 13.4 & 26.0 & 3.4 \\
\hline & 香椎神宮 & JR & 1,767 & 8,944 & 1.1 & 56.6 & 4.9 & 12.1 & 20.1 & 4.8 \\
\hline & \begin{tabular}{|l} 
舞松原 \\
\end{tabular} & JR & 1,819 & 9,636 & 2.5 & 51.6 & 3.4 & 12.7 & 17.8 & 8.8 \\
\hline & 和白 & JR & 2,030 & 11,543 & 7.3 & 32.9 & 7.4 & 9.1 & 18.5 & 8.6 \\
\hline & 奈多 & JR & 2,397 & 7,092 & 4.4 & 43.9 & 6.7 & 8.0 & 17.0 & 8.2 \\
\hline & 三苫 & 西鉄 & 3,244 & 7,636 & 4.5 & 42.1 & 2.9 & 13.0 & 21.4 & 10.8 \\
\hline & 周船寺 & JR & 9,397 & 5,148 & 13.6 & 41.4 & 8.3 & 7.0 & 18.7 & 8.6 \\
\hline & 土井 & JR & 2,197 & 6,096 & 13.3 & 38.3 & 1.4 & 6.3 & 21.2 & 7.7 \\
\hline & 香椎花園前 & 西鉄 & 2,649 & 5,763 & 12.9 & 43.9 & 13.1 & 10.5 & 17.8 & 1.5 \\
\hline & 箱崎宮前 & 地下鉄 & 5,732 & 16,916 & 9.1 & 43.5 & 10.0 & 14.2 & 21.1 & 2.0 \\
\hline & 笹原 & $J R$ & 7,381 & 13,207 & 7.6 & 49.4 & 4. 7 & 11.7 & 21.1 & 1.8 \\
\hline & 香椎宮前 & 西鉄 & 2,411 & 10,923 & 9.5 & 38.8 & 4.0 & 20.3 & 22.9 & 4.2 \\
\hline & 桜坂 & 地下鉄 & 2,532 & 10,781 & 3.2 & 49.0 & 6.7 & 23.4 & 13.9 & 3.7 \\
\hline & & 平均 & 3,554 & 9,281 & 7.0 & 45.0 & 5.0 & 11.0 & 21.0 & 5.0 \\
\hline \multirow{7}{*}{$\begin{array}{l}\text { Group } 2 \\
\text { (6駅) }\end{array}$} & 竹下 & JR & 10,126 & 16,054 & 5.8 & 33.9 & 5.6 & 6.1 & 26.3 & 21.6 \\
\hline & 今宿 & JR & 8,545 & 8,484 & 6.9 & 35.9 & 1.9 & 10.4 & 18.8 & 23.5 \\
\hline & 雁ノ栄 & JR & 668 & 3,147 & 1.5 & 38.8 & 8.4 & 6.5 & 19.4 & 21.5 \\
\hline & 西戸崎 & JR & 1,679 & 2,506 & 5.5 & 35.0 & 12.9 & 7.5 & 19.4 & 19.6 \\
\hline & 橋本 & 地下鉄 & 4,611 & 2,719 & 2.5 & 19.2 & 4.0 & 9.5 & 20.6 & 14.2 \\
\hline & 下山門 & JR & 4,277 & 7,777 & 2.1 & 28.9 & 4.6 & 1.8 & 19.5 & 37.9 \\
\hline & & 平均 & 4,984 & 6,781 & 4.0 & 32.0 & 6.0 & 7.0 & 21.0 & 23.0 \\
\hline \multirow{7}{*}{$\begin{array}{c}\text { Group } 3 \\
\text { (6駅) }\end{array}$} & 福大前 & 地下鉄 & 10,907 & 6,051 & 3.7 & 25.5 & 44.3 & 8.9 & 14.0 & 2.2 \\
\hline & 馬出九大病院前 & 地下鉄 & 8,096 & 14,341 & 5.0 & 19.2 & 42.7 & 12.0 & 19.2 & 1.9 \\
\hline & 箱崎九大前 & 地下鉄 & 6,636 & 9,064 & 7.9 & 24.8 & 34.2 & 7.3 & 19.3 & 6.0 \\
\hline & 七隈 & 地下鉄 & 6,351 & 9,187 & 3.8 & 32.8 & 40.5 & 4.3 & 15.1 & 2.0 \\
\hline & 九産大前 & JR & 12,463 & 12,790 & 3.4 & 36.6 & 22.2 & 6.0 & 19.5 & 4.8 \\
\hline & 梅林 & 地下鉄 & 1,975 & 5,978 & 2.4 & 38.0 & 21.0 & 7.5 & 21.2 & 3.5 \\
\hline & & 平均 & 7,738 & 9,569 & 4.0 & 29.0 & 34.0 & 8.0 & 18.0 & 3.0 \\
\hline \multirow{11}{*}{$\begin{array}{l}\text { Group } 4 \\
\text { (10駅) }\end{array}$} & 唐人町 & 地下鉄 & 16,523 & 16,659 & 3.5 & 55.4 & 14.9 & 5.1 & 20.4 & 0.7 \\
\hline & 高宮 & 西鉄 & 18,748 & 15,938 & 5.8 & 50.4 & 13.0 & 7.4 & 20.7 & 2.5 \\
\hline & 藤崎 & 地下鉄 & 19,797 & 28,893 & 2.7 & 47.6 & 15.9 & 6.1 & 25.4 & 2.3 \\
\hline & 雑嗆隈 & 西鉄 & 15,488 & 20,081 & 10.0 & 45.7 & 5.6 & 8.5 & 24.3 & 4.0 \\
\hline & 茶山 & 地下鉄 & 3,252 & 12,024 & 4.1 & 57.9 & 14.1 & 3.7 & 17.2 & 2.3 \\
\hline & 金山 & 地下鉄 & 4,564 & 13,386 & 3.7 & 66.7 & 3.4 & 4.1 & 19.4 & 1.7 \\
\hline & 六本松 & 地下鉄 & 6,200 & 17,561 & 5.5 & 45.8 & 13.8 & 11.2 & 21.4 & 2.1 \\
\hline & 別府 & 地下鉄 & 7,219 & 19,613 & 4.1 & 56.1 & 12.6 & 4.9 & 21.2 & 1.0 \\
\hline & 西鉄平尾 & 西鉄 & 11,912 & 21,953 & 11.1 & 49.0 & 5.2 & 5.7 & 26.0 & 3.1 \\
\hline & 薬院大通 & 地下鉄 & 4,148 & 21,721 & 13.6 & 42.3 & 12.6 & 7.1 & 20.1 & 4.2 \\
\hline & & 平均 & 10,785 & 18,783 & 6.0 & 52.0 & 11.0 & 6.0 & 22.0 & 2.0 \\
\hline \multirow{13}{*}{$\begin{array}{c}\text { Group } 5 \\
\text { (12駅) }\end{array}$} & 祗園 & 地下鉄 & 11,833 & 8,245 & 23.8 & 13.3 & 10.9 & 17.1 & 30.5 & 4.2 \\
\hline & 呉服町 & 地下鉄 & 5,438 & 11,114 & 22.9 & 16.9 & 9.4 & 12.4 & 35.4 & 2.8 \\
\hline & 千代県庁口 & 地下鉄 & 6,277 & 11,460 & 15.0 & 21.7 & 19.6 & 11.7 & 29.6 & 2.5 \\
\hline & 渡辺通 & 地下鉄 & 4,551 & 17,354 & 22.1 & 31.6 & 4.7 & 9.4 & 27.5 & 4.7 \\
\hline & 東比恵 & 地下鉄 & 16,173 & 13,102 & 28.4 & 16.7 & 7.5 & 8.7 & 26.1 & 10.2 \\
\hline & 南福岡 & JR & 16,748 & 8,840 & 9.7 & 33.8 & 6.6 & 8.6 & 31.6 & 9.7 \\
\hline & 箱崎 & JR & 8,197 & 19,605 & 9.4 & 33.1 & 5.2 & 11.4 & 30.4 & 8.9 \\
\hline & 貝塚 & 地下鉄 & 15,907 & 6,463 & 5.4 & 25.6 & 7.2 & 12.1 & 38.6 & 10.2 \\
\hline & 室見 & 地下鉄 & 13,734 & 16,391 & 3.1 & 49.0 & 1.5 & 7.5 & 33.9 & 5.0 \\
\hline & 千早 & JR & 14,049 & 9,025 & 7.0 & 23.0 & 15.5 & 27.1 & 25.1 & 2.2 \\
\hline & 吉塚 & JR & 19,666 & 18,088 & 10.4 & 24.2 & 21.0 & 14.3 & 24.7 & 4.6 \\
\hline & 大㴚公園 & 地下鉄 & 14,523 & 15,285 & 5.0 & 16.8 & 8.2 & 36.2 & 32.5 & 1.3 \\
\hline & & 平均 & 12,258 & 12,914 & 14.0 & 25.0 & 10.0 & 15.0 & 30.0 & 6.0 \\
\hline & & 全体平均 & 7,864 & 11,466 & 7.0 & 36.6 & 13.2 & 9.4 & 22.4 & 7.8 \\
\hline
\end{tabular}

売店舗の立地傾向が異なると考えられ，さらに市全体の状況を万遍 なく把握するために, 以下の方針に従って分析対象駅を選定した.

（1）駅の空間構成及び地上地下を考慮して，各グループから市営地 下鉄とそれ以外の鉄道駅を 1 駅ずつ選定する.

（2）第 3 章以降の店舗立地動向及び業種分布経年変化の分析では, 1990 年, 2000 年, 2010 年の 3 時点を予定していることから, 2005 年開業の市営地下鉄七隈線の駅を出来るだけ分析対象から除く.

（3）同グループに複数の地下鉄あるいはその他の駅が存在する場合 は，基本的に無作為に駅を抽出する，ただし，その際に出来るだけ 福岡市全域をカバーできるよう配虑する.

（4）グループ 2 については, 市営地下鉄七隈線の橋本駅 しかないため, JR と市営地下鉄に相互乗り入れている 今宿駅を調查対象として選定した.

上記の方針に従って，具体的には表 1 に示すように， グループ 1 からは和白駅, 箱崎宫前駅 ; グループ 2 か らは竹下駅, 今宿駅 ; グループ 3 からは馬出九大病院 前駅, 九産大前駅; グループ 4 からは藤崎駅, 雑餉郎駅; グループ 5 からは東比恵駅，吉塚駅，計 10 駅を調査対 象として選定した.

さらに, 本研究における分析対象駅の選定は，基 本的に乗降者数 20,000 人/日を基準としているが, 2010 年の福岡市統計書によると, 乗降者数 20,000 人 〜 30,000人/日の鉄道駅が 5 つある. 図 2 に示すよう に, 近年の乗降者数は減少あるいは横ばいの傾向にあ り, 大凡 21,000 人〜 26,000 人 / 日となっている. 分 析結果の普遍性及び妥当性を確保するために, 井尻駅 (西鉄), 香椎駅 (JR), 福工大前駅 (JR) を分析対象に 加わった. なお, 赤坂駅と中洲川端駅 (いずれも地下鉄) は都心に立地しており, 本研究の分析対象駅との性格 が異なるために, 分析対象から除外した.

表2 業種構成

\begin{tabular}{|c|c|}
\hline カテゴリー & 業種名 \\
\hline \multirow{3}{*}{$\begin{array}{l}\text { 医療系 } \\
(3 \text { 業種 })\end{array}$} & 1 歯科医院 \\
\hline & 2 内科 $\cdot$ 小児科医院 \\
\hline & 3 その他の病院 \\
\hline \multirow{2}{*}{$\begin{array}{c}\text { スーパー系 } \\
(2 \text { 業種 })\end{array}$} & 4 スーパー・コンビニ \\
\hline & 5 医薬 - 化粧品 \\
\hline \multirow{3}{*}{$\begin{array}{c}\text { 食料品系 } \\
\text { (3業種) }\end{array}$} & 6 酒店 \\
\hline & 7 米穀・青果 - 精肉 · 鮮魚 \\
\hline & 8 煙草・パン・菓子店 \\
\hline \multirow{2}{*}{$\begin{array}{c}\text { 身の回り品系 } \\
\text { (2業種) }\end{array}$} & 9 洋服 - 婦人服 - 兝服 $\cdot$ 靴 \\
\hline & 10 日用雑貨・雑貨店 \\
\hline \multirow{5}{*}{$\begin{array}{c}\text { 文化用品系 } \\
\text { (5業種) }\end{array}$} & 11 時計・貴金属・眼鏡・電機品 \\
\hline & $12 \mathrm{CD}$ ～レコード店 \\
\hline & 13 スポーツ・玩具・楽器店 \\
\hline & 14 文房具店 \\
\hline & 15 書籍・事務用品店 \\
\hline \multirow{4}{*}{$\begin{array}{l}\text { 食堂系 } \\
\text { (4業種) }\end{array}$} & 16 寿司店 \\
\hline & 17 料理・飲食店 \\
\hline & 18 喫茶店・スナック \\
\hline & 19 居酒屋・パブ \\
\hline \multirow{8}{*}{$\begin{array}{c}\text { サービス采 } \\
\text { (8業種) }\end{array}$} & 20 理 $\cdot$ 美容院 \\
\hline & 21 クリーニング \\
\hline & 22 文化教室・学習塾 \\
\hline & 23 各種事務所 \\
\hline & 24 集会 - 宿泊施設 \\
\hline & 25 金融機関 \\
\hline & 26 娛楽施設 \\
\hline & 27 不動産 - 旅行代理店 \\
\hline
\end{tabular}




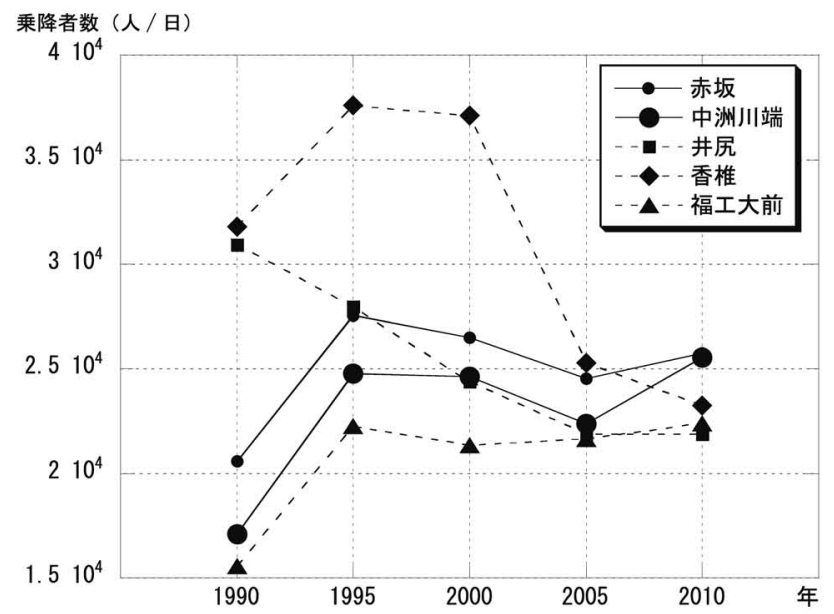

図 2 乗降者数の変化（2010 年 $2 \sim 3$ 万人/日の駅）

\section{3 対象店舗及び業種}

\section{（1）小売店舗}

鉄道駅周辺の小売店舗については, クラスター分析と同様に, 駅 の主要改札口を中心に半径 $600 \mathrm{~m}$ の範囲に設定し, 福岡市の住宅地 図(株式会社ゼンリン) ${ }^{17}$ を用いて, 圈域内に立地する店舗を集計し, GIS 上にプロットし，データの収集及び作成を行った．また，小売 店舗の立地傾向等を把握するために, 1990 年, 2000 年, 2010 年の 3 時点を分析対象とした。なお，東比恵駅は 1993 年に開業したた め, 当駅のみ 1990 年の代わりに 1993 年の住宅地図を用いた。さら に, 駅からの距離によって店舗の立地特性が異なると考えられるた め, 駅周辺エリアを半径 $200 \mathrm{~m}, 400 \mathrm{~m}, 600 \mathrm{~m}$ の同心円に分割し, 店舗立地傾向及び業種分布の分析を行う。

\section{(2) 店舗の業種構成}

店舗の業種の分け方及び定義は，福岡市商工会議所の分類基準を

表3 鉄道駅周辺の店舗及び人口の経過年変化

\begin{tabular}{|c|c|c|c|c|c|c|c|c|c|c|c|c|c|c|}
\hline \multirow{3}{*}{\multicolumn{2}{|c|}{ 駅名 }} & \multirow{4}{*}{$\begin{array}{l}\text { 距離別 } \\
0-200 \mathrm{~m}\end{array}$} & \multicolumn{6}{|c|}{ 人口の変化 } & \multicolumn{6}{|c|}{ 店舗数の変化 } \\
\hline & & & \multirow{2}{*}{$\begin{array}{c}1990 \text { 年 } \\
\text { 人口 } \\
\text { (人) }\end{array}$} & \multicolumn{2}{|c|}{ 2000年 } & \multicolumn{3}{|c|}{ 2010年 } & \multirow{2}{*}{$\begin{array}{c}\text { 1990年 } \\
\text { 店数 }\end{array}$} & \multicolumn{2}{|c|}{ 2000年 } & \multicolumn{3}{|c|}{ 2010年 } \\
\hline & & & & $\begin{array}{l}\text { 人口 } \\
\text { (人) }\end{array}$ & $\begin{array}{c}90 \text { 年比 } \\
(\%)\end{array}$ & $\begin{array}{l}\text { 人口 } \\
\text { (人) }\end{array}$ & $\begin{array}{c}00 \text { 年比 } \\
(\%)\end{array}$ & $\begin{array}{c}90 \text { 年比 } \\
(\%)\end{array}$ & & 占数 & $\begin{array}{c}90 \text { 年比 } \\
(\%)\end{array}$ & 店数 & $\begin{array}{c}00 \text { 年比 } \\
(\%)\end{array}$ & $\begin{array}{c}90 \text { 年比 } \\
(\%)\end{array}$ \\
\hline \multirow{12}{*}{$\begin{array}{l}3 \\
\text { 万 } \\
\hat{人} \\
\hat{\zeta} \\
2 \\
\frac{3}{3} \\
\hat{1} \\
\text { 日 }\end{array}$} & \multirow{4}{*}{$\begin{array}{l}\text { 井 } \\
\text { 尻 }\end{array}$} & & 8,196 & 7,940 & -3.1 & 8,013 & 0.9 & -2.2 & 124 & 161 & 29.8 & 161 & 0.0 & 29.8 \\
\hline & & $200-400 \mathrm{~m}$ & 5,567 & 5,528 & -0.7 & 5,352 & -3.2 & -3.9 & 115 & 122 & 6.1 & 101 & -17.2 & -12.2 \\
\hline & & $400-600 \mathrm{~m}$ & 10,657 & 11,115 & 4.3 & 11,170 & 0.5 & 4.8 & 99 & 103 & 4.0 & 67 & -35.0 & -32.3 \\
\hline & & 小計 & 24,420 & 24,583 & 0.7 & 24,535 & -0.2 & 0.5 & 338 & 386 & 14.2 & 329 & -14.8 & -2.7 \\
\hline & \multirow{4}{*}{$\begin{array}{l}\text { 香 } \\
\text { 椎 }\end{array}$} & $0-200 \mathrm{~m}$ & 2,209 & 522 & 14.2 & 134 & -15.4 & -3.4 & 138 & 173 & 25.4 & 20 & -30.6 & -13.0 \\
\hline & & $200-400 \mathrm{~m}$ & 9,757 & 11,196 & 14.7 & 11,363 & 1.5 & 16.5 & 148 & 152 & 2.7 & 112 & -26.3 & -24.3 \\
\hline & & $400-600 \mathrm{~m}$ & 7,747 & 7,089 & -8.5 & 5,844 & -17.6 & -24.6 & 79 & 89 & 12.7 & 82 & -7.9 & 3.8 \\
\hline & & 小計 & 19,713 & 20,807 & 5.5 & 19,341 & -7.0 & -1.9 & 365 & 414 & 13.4 & 314 & -24.2 & -14.0 \\
\hline & \multirow{3}{*}{ 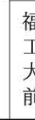 } & $0-200 \mathrm{~m}$ & 2,115 & 2,526 & 19.4 & 2,987 & 18.3 & 41.2 & 76 & 78 & 2.6 & 101 & 29.5 & 32.9 \\
\hline & & $200-400 \mathrm{~m}$ & 2,727 & 2,980 & 9.3 & 70 & 6.4 & 16 & 02 & 26 & -18.8 & 42 & 61.5 & 1.3 \\
\hline & & $400-600 \mathrm{~m}$ & 3,762 & 3,718 & -1.2 & 3,561 & -4.2 & -5.3 & 23 & 26 & 13.0 & 22 & -15.4 & -4.3 \\
\hline & & 小計 & 8,604 & 9,224 & 7.2 & 9,718 & 5.4 & 12.9 & 131 & 130 & -0.8 & 165 & 26.9 & 26.0 \\
\hline & & $-200 \mathrm{~m}$ & 1,358 & 769 & 30.3 & 07 & 17.5 & 53.1 & 37 & 37 & 0.0 & 34 & -8.1 & -8.1 \\
\hline & 和 & $200-400 \mathrm{~m}$ & 2,545 & 3,124 & 22.8 & 3,664 & 17.3 & 44.0 & 29 & 43 & 48.3 & 79 & 83.7 & 172.4 \\
\hline & 白 & $400-600 \mathrm{~m}$ & 3,964 & 4,758 & 20.0 & 5,800 & 21.9 & 46.3 & 21 & 33 & 57.1 & 15 & -54.5 & -28.6 \\
\hline & & 小計 & 7,867 & 9,651 & 22.7 & 11,543 & 19.6 & 46.7 & 87 & 113 & 29.9 & 128 & 13.3 & 47.1 \\
\hline & 箱 & $0-200 \mathrm{~m}$ & 2,089 & 1,938 & -7.2 & 2,00 & 3.3 & -4.2 & 30 & 23 & -23.3 & 16 & -30.4 & -46.7 \\
\hline & 崎 & $200-400 \mathrm{~m}$ & 8,910 & 8,601 & -3.5 & 02 & 5.0 & 1 & 157 & 44 & -8.3 & 131 & -9.0 & -16.6 \\
\hline & 宮 & $400-600 \mathrm{~m}$ & 6,359 & 5,858 & -7.9 & 5,886 & 0.5 & -7 . & 131 & 109 & -16.8 & 96 & -11.9 & -26.7 \\
\hline & 亩 & 小計 & 17,358 & 16,397 & -5.5 & 16,916 & 3.2 & -2.5 & 318 & 276 & -13.2 & 243 & -12.0 & -23.6 \\
\hline & & $0-200 \mathrm{~m}$ & 3,279 & 3,260 & -0.6 & 3,261 & 0.0 & -0.5 & 56 & 50 & -10.7 & 48 & -4.0 & -14.3 \\
\hline & 竹 & $200-400 \mathrm{~m}$ & 5,213 & 6,081 & 16.7 & 7 & 8 & 43 & 21 & 6 & 23.8 & 0 & 15.4 & 2.9 \\
\hline & 下 & $400-600 \mathrm{~m}$ & 5,514 & 5,216 & -5.4 & 5,323 & 2.1 & -3 & 39 & 39 & 0.0 & 0 & 28.2 & 28.2 \\
\hline & & 小計 & 14,006 & 4,557 & 3.9 & 16,05 & 3 & 14 & 116 & 115 & -0.9 & 128 & 11.3 & 0.3 \\
\hline & & $0-200 \mathrm{~m}$ & 2,384 & 881 & 8.3 & 8 & 1.4 & 34. & 5 & & 9.1 & 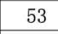 & -11.7 & -3.6 \\
\hline & 今 & $200-400 \mathrm{~m}$ & 812 & 37 & 27.7 & 1,059 & 2.1 & 30 & 57 & 81 & 42.1 & 46 & -43.2 & -19.3 \\
\hline & 宿 & $400-600 \mathrm{~m}$ & 3,139 & 4,020 & 28.1 & 4,213 & 4.8 & 34 & 17 & 21 & 23.5 & 31 & 47.6 & 82.4 \\
\hline & & 小計 & 6,335 & 7,638 & 20.6 & 8,484 & 11.1 & 9 & 129 & 162 & 25.6 & 130 & -19.8 & 0.8 \\
\hline & $\begin{array}{l}\text { 星 } \\
\text { 出 }\end{array}$ & $0-200 \mathrm{~m}$ & 2,024 & 2,383 & 17.7 & 2,509 & 5.3 & 0 & 71 & 60 & -15.5 & 67 & 11.7 & -5.6 \\
\hline & & $200-400 \mathrm{~m}$ & 5,334 & 4,240 & -20.5 & 5,223 & 3.2 & -2 & 108 & 100 & -7.4 & 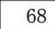 & -32.0 & -37.0 \\
\hline 万 & 天 & $400-600 \mathrm{~m}$ & 6,141 & 964 & 13.4 & 6,609 & -5.1 & 7.6 & 96 & 57 & -40.6 & I & 12.3 & -33.3 \\
\hline 以 & 首 & 小計 & 13,499 & 13,587 & 0.7 & 14,341 & 5.5 & 6.2 & 275 & 217 & -21.1 & 199 & -8.3 & -27.6 \\
\hline 下 & 九 & $-200 \mathrm{~m}$ & 264 & & 1. & & & & & & -6.3 & & 60.0 & 0.0 \\
\hline j & 产 & $200-400 \mathrm{~m}$ & 319 & 8 & 9.0 & 4 & 3.7 & & 1 & & 0.0 & 6 & -5.9 & 5.9 \\
\hline 日 & & $400-600 \mathrm{~m}$ & 837 & 639 & -4.1 & 4,593 & -1.0 & -5 & $4 t$ & $t$ & 2.2 & 50 & -4.3 & -2.2 \\
\hline & & 小言 & 12,420 & 45 & 1.8 & 12 & 1.1 & & 9 & 4 & -1.1 & 109 & 16.0 & 4.7 \\
\hline & & $0-200 \mathrm{~m}$ & 615 & & 15.4 & & 1.8 & 13 & 73 & 84 & 15.1 & & 10.7 & 27.4 \\
\hline & 藤 & $200-400 \mathrm{~m}$ & 9,446 & 10,232 & 8.3 & . & 12.5 & & 100 & 100 & 0.0 & 82 & -18.0 & -18.0 \\
\hline & 崎 & $400-600 \mathrm{~m}$ & 7,686 & & .3 & & 5.9 & & & & 10.1 & 1 & -7.5 & 1.8 \\
\hline & & 小言 & 22,747 & 27 & 19.2 & 28,893 & 6.6 & 27.0 & & 0 & 7.8 & 6 & -5.9 & 1.4 \\
\hline & & $-200 \mathrm{~m}$ & 6,123 & & 4.2 & 6 & 4 & 1. & & 1 & -28.2 & 11 & 1.6 & -27.1 \\
\hline & & $200-400 \mathrm{~m}$ & 832 & & 0. & 5,6 & -3.0 & -2 . & & 25 & 20.9 & 245 & -3.9 & 16.1 \\
\hline & & $400-600 \mathrm{~m}$ & 7,573 & & 6.2 & & 1. & 7 & & & 1.3 & 81 & -43.1 & -42.4 \\
\hline & & 小計 & 19,528 & 20,287 & 3.9 & 20,081 & -1.0 & 2.8 & 624 & 596 & -4.5 & 523 & -12.2 & -16.2 \\
\hline & & $0-200 \mathrm{~m}$ & 2,197 & 2,568 & 16.9 & 2,970 & 15.7 & 35.2 & 34 & 28 & -17.6 & 69 & 146.4 & 102.9 \\
\hline & 匊 & $200-400 \mathrm{~m}$ & 4,2 & & 16.5 & & 8 & 2 & 102 & 69 & -32.4 & 1 & 31.9 & -10.8 \\
\hline & & $400-600 \mathrm{~m}$ & & & 13.0 & & & 40 & 00 & 40 & -47.7 & 69 & 50.0 & -21.6 \\
\hline & & 小計 & 9,723 & 11,240 & 15.6 & 13,102 & 6 & 34.8 & 224 & 143 & -36.2 & 229 & 60.1 & 2.2 \\
\hline & & $0-200 \mathrm{~m}$ & 2,192 & 950 & 34.6 & 66 & 17.5 & 58. & 35 & 34 & -2.9 & 40 & 17.6 & 14.3 \\
\hline & 吉 & $200-400 \mathrm{~m}$ & 6,497 & 085 & -6.3 & 0,1 & 11.1 & & 150 & 134 & -10.7 & 95 & -29.1 & -36.7 \\
\hline & & $400-600 \mathrm{~m}$ & 7,195 & 7,516 & 4.5 & 7,859 & 4.6 & 9.2 & 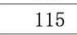 & 97 & -15.7 & 50 & -48.5 & -56.5 \\
\hline & & 小計 & 15,884 & 16,551 & 4.2 & 18,088 & 9.3 & 13.9 & SOU & 265 & -11.7 & 185 & -30.2 & -38.3 \\
\hline
\end{tabular}

2) 文字網掛け 1990 年から2010年にかけて人口と店舗の増減が異なる地域, 数字網掛け口人口と店舗とも増加か減少する.
参考にしている ${ }^{18)}$. 表 2 に示すように，医 療系 3 業種, スーパー系 2 業種, 食料品系 3 業種, 身の回り品系 2 業種, 文化用品系 5 業種, 食堂系 4 業種, サービス系 8 業種 の計 27 業種とした.

\section{3. 店舗の分布実態 \\ 3.1 経年変化}

全調査対象地域における 1990 年, 2000 年, 2010 年の 3 時点の店舗数を表 3 に示す.

まず，1990 年から 2000 年にかけて，店 舗が増加している地域は, 井尻・香椎・和 白・今宿・藤崎の駅周辺である，その中で も和白と今宿の増加率は，それぞれ $29.9 \%$ と $25.6 \%$ と大きく, 目立っている. 逆に, 箱崎宮前・馬出九大病院前・雑䬲隈・東比恵・ 吉塚地域の店舗は減少した. 福工大前・竹下. 九産大前地域では店舗の増減がほとんど見 られない。

次に, 2000 年から 2010 年にかけて, 福 工大前・和白 - 竹下 $\cdot$ 九産大前・東比恵地 域では店舗が増加した．その中で，1993 年 に開業した東比恵駅の周辺地域において, 2000 年の 143 店舗が 2010 年の 229 店舗に 比べて, 約 $60.1 \%$ を急増している. 逆に, ほかの 8 地域の店舗は減少していた。その 中で, 吉塚地域の店舗は約 $30.2 \%$ をきく 減少した。

さらに, 1990 年と 2010 年の両時点の比 較により，この 20 年閒で福工大前 $(26.0 \%)$ • 和白 $(47.1 \%)$ - 竹下 $(10.3 \%)$. 九産大前 (14.7\%)の 4 地域のみにおいて店舗数が増 えた。他の地域では店舗が減少するかほと んど変化がないことから，鉄道駅周辺地域 に立地する店舗は減少する傾向にあり，と くに 2000 年から 2010 年にかけて, この傾 


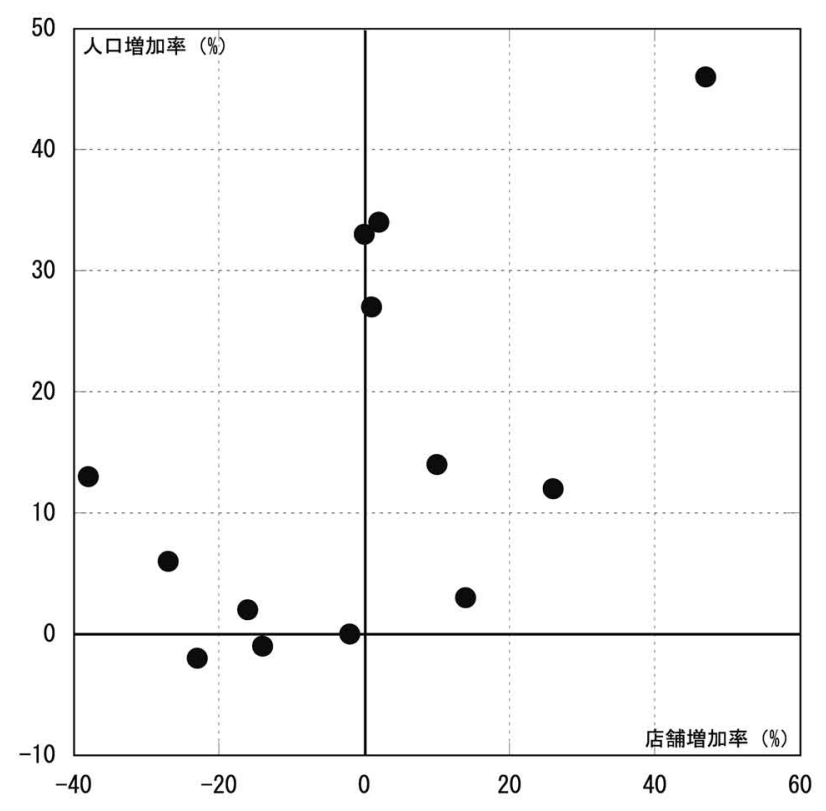

図 $31990 ２ 010$ 年の人口と店舗の増減率

向が顕著になったと言える.

\section{2 店舗数と人口の増減}

表 3 より, 対象地域の人口と店舗の経年変化についてみると, ま ず, 1990 年と 2000 年の両時点における人口と店舗の増減の程度が 異なるもの, 両方とも増加したのは井尻・香椎・和白・今宿・藤崎 の 5 地域であり, 両方とも減少したのは箱崎宮前のみである.

次に, 2000 年と 2010 年の両時点についてみると, 人口と店舗と 共に増加したのは福工大前 - 和白 - 竹下 - 九産大前 - 東比恵の 5 地 域であり, 共に減少したのは井尻・香椎・雑飾隈の 3 地域である. さらに, 1990 年から 2010 年にかけての 20 年閒をみると, 香椎・福 工大前・和白 $\cdot$ 箱崎宮前 - 竹下. 今宿 $\cdot$ 九産大前 $\cdot$ 藤崎 - 東比恵の 9 地域では，同様な傾向がみられる.

さらに，図 3 をみると，1990 年より 2010 年の閒，ほとんどの駅 の周辺人口が増加しているに対して, 周辺店舗の増加と減少の駅は 約半々となっている. 特に人口増加の著しい駅の周辺店舗数は増加 しているか，横ばいになっている．逆に人口減少と増加幅の小さい 駅においては，周辺店舗数は減少傾向にあると言える.

李氏ら ${ }^{16)}$ の研究では, 鉄道駅周辺の地域施設の発生は利用圈人口, 用途地域, 駅からの距離, 幹線道路と位置関係という 4 要因との相 関関係が強いと指摘している. つまり, 鉄道駅周辺の地域施設の集 積に影響を与える要因の一つは人口であると考えられるが，以上の 分析結果により駅周辺 $600 \mathrm{~m}$ 圈内における小売店舗の発生に限って は，人口増加率の大きさによって傾向が異なる. つまり，人口増加 率が大きい場合, 小売店舗は増加傾向にあり, 逆に, 人口増加率の 小さいあるいは横ばいの場合, 小売店舗は減少する傾向にあること が分かった.

\section{3 店舗立地と乗降数の関係}

ここでは, 1990 年, 2000 年, 2010 年の 3 時点に駅からの距離別の店 舗発生と乗降数の関係についてみる (表 3 ).

まず, 乗降数 20,000 人〜 30,000人 / 日の 3 調査対象地域においては, 駅から $0 \mathrm{~m} \sim 200 \mathrm{~m}$ の圈域に立地する店舗数は, 他の圈域 $(200 \mathrm{~m} \sim$ $400 \mathrm{~m}$ と $400 \mathrm{~m} \sim 600 \mathrm{~m}$ ) に比べて多く発生しており, 駅から離れるに従っ
て，店舗が少なくなる傾向がある.

次に, 乗降数 20,000 人以下/日の 10 地域においては, 和白·箱崎宮前· 今宿・馬出九大病院前・雑餉隈・東比恵・吉塚の 7 地域では，駅を中心 に半径 $200 \mathrm{~m} \sim 400 \mathrm{~m}$ の圈域に店舗が多く分布している. 九産大前と藤 崎の 2 地域では半径 $400 \mathrm{~m} \sim 600 \mathrm{~m}$ の圈域に, 竹下地域では半径 $0 \mathrm{~m}$ 〜 $200 \mathrm{~m}$ の圈域に店舗が多く分布していることが分かる.

つまり, 乗降者数の多い駅では，小売店舗がより駅に近い場所に立地 し, 乗降数 20,000 人以下/日の小規模駅では, 駅から少し離れた場所 に立地する傾向がある.

\section{4 店舗の立地パターン}

鉄道駅周辺地域の店舗の分布特性を明らかにするために，ここで は最近隣尺度を用いて，店舗の立地パターンを判定する．最近隣尺 度はもともとは生態学者によって植生群落や動物集団の分布を測定 寸るために考察され，以下のように定義する ${ }^{19)}$.

$$
R=r_{0} / r_{E}
$$

ここで使われている記号を次のように定義する.

$r_{0}$ : 現実に分布する $n$ 個の店舗に関し，各店舗の最近接店舗まで の直線距離 $r_{i}$ の平均值は，次式のように表せる.

$$
r_{0}=\sum_{i} r_{i} / n
$$

$r_{E}$ : 理論的なランダム分布（ポアソン分布）を前提とした場合, $\mathrm{n}$ 個の店舗について, 各店舗の最近接店舗までの直線距離の平均であ り, 次式で定義される.

$$
r_{E}=\frac{1}{2} \sqrt{n / A}
$$

ただし, A は対象地域の面積であるため, $n / A$ は店舗の分布密度に 相当する.

算出した $R$ 值によって，店舗の立地パターンを判定される. $R<$ 1 のときは凝集分布を示し，つまり，調查地域に立地していた店舗 が互いに近くに立地していることを示す．R>1のときはランダム 分布の傾向を示しており, 調査地域に立地していた店舗がそれぞれ 離れて分布するものと見なされる.

表 4 に分析対象駅周辺に立地する小売店舗の計算結果を示す。ま ず，Rの平均值についてみると, 1990 年, 2000 年, 2010 年の平均 值がそれぞれ $0.593 ， 0.584 ， 0.550$ である.つまり，全調查地域に 立地している店舗は凝集分布の傾向にあり,また 1990 年, 2000 年,

\begin{tabular}{|c|c|c|c|c|c|c|c|c|c|}
\hline \multirow{3}{*}{ 駅名 } & \multirow{3}{*}{$\begin{array}{c}\text { 1990年 } \\
\text { R值 }\end{array}$} & \multicolumn{3}{|c|}{ 2000年 } & \multicolumn{5}{|c|}{ 2010年 } \\
\hline & & \multirow{2}{*}{ R值 } & \multicolumn{2}{|c|}{ 90年比 } & \multirow{2}{*}{ R値 } & \multicolumn{2}{|c|}{ 00年比 } & \multicolumn{2}{|c|}{90 年比 } \\
\hline & & & 差 & 変化 & & 差 & 変化 & 差 & 変化 \\
\hline 井尻 & 0.588 & 0.596 & 0.008 & $x$ & 0.576 & -0.020 & 0 & -0.012 & 0 \\
\hline 香椎 & 0.548 & 0.565 & 0.017 & $x$ & 0.470 & -0.095 & 0 & -0.078 & 0 \\
\hline 福工大前 & 0.505 & 0.485 & -0.020 & 0 & 0.512 & 0.027 & $x$ & 0.006 & $x$ \\
\hline 和白 & 0.554 & 0.481 & -0.073 & 0 & 0.517 & 0.036 & $x$ & -0.037 & 0 \\
\hline 箱崎宮前 & 0.639 & 0.629 & -0.010 & 0 & 0.631 & 0.002 & $x$ & -0.009 & 0 \\
\hline 竹下 & 0.563 & 0.578 & 0.015 & $x$ & 0.504 & -0.074 & 0 & -0.059 & 0 \\
\hline 今宿 & 0.616 & 0.597 & -0.019 & 0 & 0.655 & 0.058 & $x$ & 0.039 & $x$ \\
\hline 馬出九大辡院前 & 0.459 & 0.424 & -0.035 & 0 & 0.397 & -0.027 & 0 & -0.062 & 0 \\
\hline 九産大前 & 0.552 & 0.562 & 0.010 & $x$ & 0.545 & -0.017 & 0 & -0.007 & 0 \\
\hline 藤崎 & 0.583 & 0.590 & 0.007 & $x$ & 0.485 & -0.105 & 0 & -0.098 & 0 \\
\hline 雑餉隈 & 0.637 & 0.608 & -0.029 & 0 & 0.591 & -0.017 & $\mathrm{O}$ & -0.045 & 0 \\
\hline 東比恵 & 0.735 & 0.752 & 0.017 & $x$ & 0.593 & -0.159 & 0 & -0.142 & 0 \\
\hline 吉塚 & 0.726 & 0.730 & 0.004 & $x$ & 0.671 & -0.059 & 0 & -0.055 & 0 \\
\hline 平均 & 0.593 & 0.584 & -0.008 & 0 & 0.550 & -0.035 & 0 & -0.043 & 0 \\
\hline
\end{tabular}
2010 年の時系列をみると，值が小さくなっており，近年このような

表4 店舗の立地パターン 
傾向が顕著になっていると言える.

また, 対象地域別からみると, 1990 年〜 2000 年には福工大前・和白・ 箱崎宮前・今宿・馬出九大病院前・杂倠凔隈の 6 地域, 2000 年 2010 年には井尻 - 香椎 - 竹下 - 馬出九大病院前 - 九産大前 - 藤崎 - 雑餉 隈・東比恵・吉塚の 9 地域が凝集分布の傾向にあり, 1990 年と 2010 年の両時点を比較しても, 福工大前と今宿地域を除くほかの 11 地域 ともR值が小さくなり，つまり，ほとんどの地域においては，店舗 が互いに近くに分布する傾向はあることがわかった．

以上のように, 1990 年から約 20 年間の間, 小規模鉄道駅周辺に 立地する小売店舗が一部の駅を除き, 減少か横ばいの傾向にあり, 周辺人口増加の駅周辺でも, 必ずしも店舗が増加するとは限らない. 一方, 駅周辺の店舗立地状況については, やや敌集分布, つまり店 舗同士が近く立地する傾向にあり，これは店舗数の減少を背景に集 客力が図られていると考えられる。

\section{4. 業種の分布実態}

\section{1 業種の経年変化}

調査全地域における 1990 年, 2000 年, 2010 年の 3 時点の業種ご との店舗数を表 5 に示す.

まず，1990 年から 2000 年にかけて，医療系と食堂系がそれぞれ 9. 7\%，8.1\%を増えた．食料品系と身の回り品系がそれぞれ $18.1 \%$, 19. $3 \%$ を減少した。 スーパー系と文化用品系及びサービス系が大き な変化は見られない，次に，2000 年から 2010 年にかけて，医療系 とサービス系がそれぞれ $11.8 \% ， 8.2 \%$ を増加したが，ほかの 5 業 種の店舗数が減少した. その中でも, 身の回り品系と文化用品系も 約 39\%を激減した。ささらに，1990 年と 2010 年の 2 時点を比較して みると，店数が増えた業種として医療系・食堂系・サービス系であ るが, ほかの 4 業種の店舗数が減少した。 その中でも, 身の回り品 系の店舗数が 353 店舗から 175 店舖に約 $50 \%$ 大きく減少した.

また, 表 5 より，3 調查時点における各業種のカテゴリーについ てみると, 医療系ではその他の病院, 食料品系では米穀・青果・精肉・ 鮮魚, 文化用品系では時計・貴金属・眼鏡・電機品, 食堂系では料理・ 飲食店の店数はそれぞれ業種の大きな割合を占めていることが分か る. 一方，スーパー系・身の回り品系・サービス系の店数においては, 調査時点によって変化が大きく, 近年, 文化教室・学習塾や各種事 務所の店舗数は比較的に多くなっている.

\section{2 調査地域ごとの業種分布}

ここで，まず $1990 〜 2010$ 年までの間，駅周辺人口は $10 \%$ 以上増 加した福工大前, 和白, 竹下, 今宿, 藤崎, 東比恵, 吉塚の 7 地域 における業種ごとの店舗数の増減についてみる. 表 6 に示すように, 医療系は吉塚を除く 6 地域, スーパー系は福工大前, 和白, 吉塚の 3 地域, 食料品系は和白のみ, 身の回り品系はなし, 文化用品系は 竹下のみ, 食堂系は福工大前, 和白, 今宿の 3 地域, サービス系は 福工大前, 和白, 今宿, 藤崎, 東比恵の 5 地域においてそれぞれの 店舗数が増加した．前述のように全調查対象地域の人口が増加，店 舗数が減少する傾向の中で, 医療系及びサービス系の店舗増加が目 立っている. 一方, 食料品系と身の回り品系の店舗数は, 周辺人口 の増減と関倸なく，ほぼすべての地域において大きく減少している.

次いで, 1990 年から 2010 年にまでの地域別における業種ごとの変化 についてみると, 福工大前, 和白の 2 地域では 3 業種以上の添付は増
加傾向にあるに対して，医療系とサービス系を除けば，ほかの 5 業種に おいて店舗が全て減少あるいは横ばいになっている地域としては，井尻， 香椎，藤崎，雑餉隈，東比恵の 5 地域である.

以上のように，地域によって業種ごとの店舗数の増減は異なるも の, 食料品系と身の回り品系に関しては, 周辺人口の増減と関係なく, ほぼすべての地域において大きく減少していることから，以前から 指摘されているように，この 2 業種は郊外等の大型商業施設の影響 を受けているが，大型店の出店規制を実施している今日でも，店舗 が減り続けており，駅周辺地域に日常買い物の利便性を向上させる ために, この 2 業種の店舗の減少をいかに食い止めるのは重要であ ると考えられる.

\section{3 業種間の分布対応パターン}

3.4 節では, 最近隣尺度を用いて対象地域ごとの店舗立地パター ンを判定するものであったが，業種別の間の分布対応パターンを測 る尺度として，ここでは，最近隣空間的随伴尺度を用いる. 2 つの 業種を A，Bで区別すると，次のように定義する ${ }^{19)}$.

$$
R^{\prime}=r_{0}^{\prime} / r_{E}^{\prime}
$$

また, $r_{0}^{\prime}: \mathrm{A}$ 業種の店舗と $\mathrm{B}$ 業種の店舗の最近接距離であり, 次の ように定義される。

$$
r_{0}^{\prime}=\left(\sum_{i}^{N_{A}} d_{A B i}+\sum_{j}^{N_{B}} d_{B A j}\right) / N
$$

\begin{tabular}{|c|c|c|c|c|c|c|c|}
\hline \multirow{2}{*}{\multicolumn{2}{|c|}{ 業種分類・カテゴリー }} & \multirow{3}{*}{$\begin{array}{r}\text { 1990年 } \\
\text { 店数 } \\
94\end{array}$} & \multicolumn{2}{|c|}{ 2000年 } & \multicolumn{3}{|c|}{ 2010年 } \\
\hline & & & \multirow{2}{*}{\multicolumn{2}{|c|}{\begin{tabular}{c|c} 
店数 & $\begin{array}{c}90 \text { 年比 } \\
(\%)\end{array}$ \\
109 & 16.0 \\
\end{tabular}}} & \multirow{2}{*}{$\frac{\text { 店数 }}{117}$} & \multirow{2}{*}{$\begin{array}{c}\begin{array}{c}00 \text { 年比 } \\
(\%)\end{array} \\
7.3\end{array}$} & \multirow{2}{*}{$\begin{array}{c}\begin{array}{c}90 \text { 年比 } \\
(\%)\end{array} \\
24.5\end{array}$} \\
\hline \multirow{4}{*}{$\begin{array}{l}\text { 医 } \\
\text { 療 } \\
\text { 系 }\end{array}$} & 齒科医院 & & & & & & \\
\hline & 内科・ 小児科医院 & 31 & 46 & 48.4 & 56 & 21.7 & 80.6 \\
\hline & その他の病院 & 206 & 208 & 1.0 & 233 & 12.0 & 13.1 \\
\hline & 小計 & 331 & 363 & 9.7 & 406 & 11.8 & 22.7 \\
\hline \multirow{3}{*}{$\begin{array}{l}\pi \\
1 \\
j \\
1 \\
1 \\
3 \\
\end{array}$} & スーパー・コンビニ & 157 & 133 & -15.3 & 128 & -3.8 & -18.5 \\
\hline & 医薬・化粧品店 & 151 & 165 & 9.3 & 129 & -21.8 & -14.6 \\
\hline & 小計 & 308 & 298 & -3.2 & 257 & -13.8 & -16.6 \\
\hline \multirow{4}{*}{$\begin{array}{l}\text { 食 } \\
\text { 料 } \\
\text { 品 } \\
\text { 采 }\end{array}$} & 酒店 & 87 & 58 & -33.3 & 32 & -44.8 & -63.2 \\
\hline & 米穀 - 青果 - 精肉 - 鮮魚 & 215 & 189 & -12.1 & 139 & -26.5 & -35.3 \\
\hline & 煙草・パン・菓子店 & 119 & 98 & -17.6 & 97 & -1.0 & -18.5 \\
\hline & 小計 & 421 & 345 & -18.1 & 268 & -22.3 & -36.3 \\
\hline \multirow{3}{*}{$\begin{array}{l}\text { 身 } \\
\text { o } \\
\text { 回 } \\
\text { 品 } \\
\text { 品 } \\
\text { 系 }\end{array}$} & 洋服 - 婦人服 - 呉服 - 靴 & 146 & 121 & -17.1 & 91 & -24.8 & -37.7 \\
\hline & 日用品・雑貨店 & 207 & 164 & -20.8 & 84 & -48.8 & -59.4 \\
\hline & 小計 & 353 & 285 & -19.3 & 175 & -38.6 & -50.4 \\
\hline \multirow{6}{*}{$\begin{array}{l}\text { 文 } \\
\text { 化 } \\
\text { 用 } \\
\text { 品 } \\
\text { 系 }\end{array}$} & 時計・貴金属・眼鏡・電機 & 112 & 98 & -12.5 & 81 & -17.3 & -27.7 \\
\hline & CD・レコード店 & 15 & 22 & 46.7 & 5 & -77.3 & -66.7 \\
\hline & スポーツ・玩具・楽器店 & 19 & 21 & 10.5 & 15 & -28.6 & -21.1 \\
\hline & 文房具店 & 30 & 27 & -10.0 & 11 & -59.3 & -63.3 \\
\hline & 書籍・事務用品店 & 39 & 37 & -5.1 & 13 & -64.9 & -66.7 \\
\hline & 小計 & 215 & 205 & -4.7 & 125 & -39.0 & -41.9 \\
\hline \multirow{5}{*}{$\begin{array}{l}\text { 食 } \\
\text { 堂 } \\
\text { 系 }\end{array}$} & 寿司店 & 68 & 52 & -23.5 & 42 & -19.2 & -38.2 \\
\hline & 料理・飲食店 & 416 & 460 & 10.6 & 457 & -0.7 & 9.9 \\
\hline & 喫茶店・スナック & 272 & 275 & 1.1 & 247 & -10.2 & -9.2 \\
\hline & 居酒屋・パブ & 101 & 139 & 37.6 & 133 & -4.3 & 31.7 \\
\hline & 小計 & 857 & 926 & 8.1 & 879 & -5.1 & 2.6 \\
\hline \multirow{10}{*}{$\begin{array}{l}\text { サ } \\
\text { l } \\
\text { ビ } \\
\text { 采 } \\
\text { 系 }\end{array}$} & 理·美容院 & 204 & 209 & 2.5 & 149 & -28.7 & -27.0 \\
\hline & クリーニング & 160 & 155 & -3.1 & 98 & -36.8 & -38.8 \\
\hline & 文化教室・学習塾 & 112 & 99 & -11.6 & 170 & 71.7 & 51.8 \\
\hline & 各種事務所 & 56 & 59 & 5.4 & 202 & 242.4 & 260.7 \\
\hline & 集会. 宿泊施設 & 28 & 22 & -21.4 & 24 & 9.1 & -14.3 \\
\hline & 金融機関 & 77 & 84 & 9.1 & 70 & -16.7 & -9.1 \\
\hline & 娱楽施設 & 56 & 72 & 28.6 & 69 & -4.2 & 23.2 \\
\hline & 不動産 - 旅行代理店 & 106 & 93 & -12.3 & 76 & -18.3 & -28.3 \\
\hline & 小計 & 799 & 793 & -0.8 & 858 & 8.2 & 7.4 \\
\hline & 合計 & 3284 & 3215 & -2.1 & 2968 & -7.7 & -9.6 \\
\hline
\end{tabular}

表5 業種構成の経過年変化 
表6 調査対象地域ごとの業種経過年変化

\begin{tabular}{|c|c|c|c|c|c|c|c|c|c|c|c|c|c|c|c|c|c|c|}
\hline \multirow{2}{*}{\multicolumn{2}{|c|}{ 駅名 }} & \multirow{3}{*}{$\begin{array}{l}\text { 年代 } \\
1990\end{array}$} & \multicolumn{2}{|c|}{ 人口 } & \multicolumn{2}{|c|}{ 医療系 } & \multicolumn{2}{|c|}{ スーパー系 } & \multicolumn{2}{|c|}{ 食料品系 } & \multicolumn{2}{|c|}{ 身の回り品系 } & \multicolumn{2}{|c|}{ 文化用品系 } & \multicolumn{2}{|c|}{ 食堂系 } & \multicolumn{2}{|c|}{ サービス系 } \\
\hline & & & (人) & $\begin{array}{c}\text { 増減率 } \\
\%\end{array}$ & 店数 & $\begin{array}{c}\text { 増減率 } \\
\%\end{array}$ & 店数 & $\begin{array}{c}\text { 増減率 } \\
\%\end{array}$ & 店数 & $\begin{array}{c}\text { 增減率 } \\
\%\end{array}$ & 店数 & $\begin{array}{c}\text { 増減率 } \\
\quad \%\end{array}$ & 店数 & $\begin{array}{c}\text { 増減率 } \\
\%\end{array}$ & 店数 & $\begin{array}{c}\text { 増減率 } \\
\%\end{array}$ & 店数 & $\begin{array}{c}\text { 増減率 } \\
\%\end{array}$ \\
\hline \multirow{9}{*}{$\begin{array}{l}3 \\
\text { 万 } \\
\hat{\lambda} \\
\zeta \\
2 \\
\text { 方 } \\
\text { 人 } \\
j \\
\text { 日 }\end{array}$} & \multirow{3}{*}{$\begin{array}{l}\text { 井 } \\
\text { 尻 }\end{array}$} & & 24,420 & \multirow{3}{*}{0.5} & 35 & \multirow{3}{*}{20.0} & 39 & \multirow{3}{*}{-28.2} & 38 & \multirow{3}{*}{-5.3} & 25 & \multirow{3}{*}{-4.0} & 20 & \multirow{3}{*}{-60.0} & 89 & \multirow{3}{*}{-2.2} & 92 & \\
\hline & & 2000 & 24,583 & & 49 & & 48 & & 37 & & 27 & & 20 & & 94 & & 111 & 13.0 \\
\hline & & 2010 & 24,535 & & 42 & & 28 & & 36 & & 24 & & 8 & & 87 & & 104 & \\
\hline & 香 & 1990 & 19,713 & & 41 & & 39 & & 39 & & 19 & & 27 & & 102 & & 98 & \\
\hline & 椎 & 2000 & 20,807 & -1.9 & 52 & 24.4 & 45 & -17.9 & 35 & -59.0 & 19 & -52.6 & 34 & -51.9 & 126 & -20.6 & 103 & 14.3 \\
\hline & & 2010 & 19,341 & & 51 & & 32 & & 16 & & 9 & & 13 & & 81 & & 112 & \\
\hline & 福 & 1990 & 8,604 & & 14 & & 13 & & 14 & & 6 & & 4 & & 45 & & 35 & \\
\hline & 大 & 2000 & 9,224 & 12.9 & 16 & 85.7 & 16 & 38.5 & 10 & -50.0 & 9 & 0.0 & 5 & 0.0 & 39 & 28.9 & 35 & 31.4 \\
\hline & & 2010 & 9,718 & & 26 & & 18 & & 7 & & 6 & & 4 & & 58 & & 46 & \\
\hline & & 1990 & 7,867 & & 12 & & 10 & & 5 & & 4 & & 6 & & 23 & & 27 & \\
\hline & 白 & 2000 & 9,651 & 46.7 & 12 & 16.7 & 10 & 40.0 & 11 & 40.0 & 2 & -25.0 & 9 & 0.0 & 39 & 91.3 & 30 & 48.1 \\
\hline & & 2010 & 11,543 & & 14 & & 14 & & 7 & & 3 & & 6 & & 44 & & 40 & \\
\hline & 箱 & 1990 & 17,358 & & 30 & & 14 & & 54 & & 66 & & 16 & & 68 & & 70 & \\
\hline & 官 & 2000 & 16,397 & -2.5 & 23 & -16.7 & 20 & 42.9 & 37 & -50.0 & 50 & -62.1 & 19 & 12.5 & 69 & -2.9 & 58 & -11.4 \\
\hline & & 2010 & 16,916 & & 25 & & 20 & & 27 & & 25 & & 18 & & 66 & & 62 & \\
\hline & 竹 & 1990 & 14,006 & & 9 & & 10 & & 19 & & 8 & & 5 & & 26 & & 39 & \\
\hline & 下 & 2000 & 14,557 & 14.6 & 9 & 122.2 & 9 & -30.0 & 21 & -10.5 & 10 & -50.0 & 4 & 60.0 & 29 & 19.2 & 33 & 5.1 \\
\hline & & 2010 & 16,054 & & 20 & & 7 & & 17 & & 4 & & 8 & & 31 & & 41 & \\
\hline & 今 & 1990 & 6,335 & & 12 & & 14 & & 15 & & 13 & & 12 & & 25 & & 38 & \\
\hline & 宿 & 2000 & 7,638 & 33.9 & 19 & 91.7 & 16 & -28.6 & 18 & -46.7 & 14 & -46.2 & 9 & -58.3 & 38 & 36.0 & 48 & 13.2 \\
\hline & & 2010 & 8,484 & & 23 & & 10 & & 8 & & 7 & & 5 & & 34 & & 43 & \\
\hline 2 & 馬 & 1990 & 13,499 & & 29 & & 16 & & 41 & & 50 & & 20 & & 60 & & 59 & \\
\hline 万 & 芰 & 2000 & 13,587 & 6.2 & 20 & -17.2 & 19 & 50.0 & 30 & -43.9 & 32 & -74.0 & 19 & -80.0 & 54 & 8.3 & 43 & -22.0 \\
\hline$\hat{1}$ & 大 & 2010 & 14,341 & & 24 & & 24 & & 23 & & 13 & & 4 & & 65 & & 46 & \\
\hline 姿 & 九 & 1990 & 12,420 & & 9 & & 2 & & 13 & & 9 & & 7 & & 33 & & 22 & \\
\hline / & 笑 & 2000 & 12,645 & 3.0 & 9 & 55.6 & 3 & 0.0 & 4 & -76.9 & 3 & -11.1 & 4 & -28.6 & 44 & 39.4 & 27 & 40.9 \\
\hline 日 & 前 & 2010 & 12,790 & & 14 & & 2 & & 3 & & 8 & & 5 & & 46 & & 31 & \\
\hline & & 1990 & 22,747 & & 40 & & 30 & & 36 & & 14 & & 18 & & 65 & & 79 & \\
\hline & $\begin{array}{l}\text { 滕 } \\
\text { 㥓 }\end{array}$ & 2000 & 27,110 & 27.0 & 44 & 35.0 & 30 & -23.3 & 31 & -47.2 & 20 & 0.0 & 20 & -33.3 & 73 & 4. 6 & 86 & 21.5 \\
\hline & & 2010 & 28,893 & & 54 & & 23 & & 19 & & 14 & & 12 & & 68 & & 96 & \\
\hline & 雑 & 1990 & 19,528 & & 51 & & 70 & & 69 & & 56 & & 38 & & 219 & & 121 & \\
\hline & 餉 & 2000 & 20,287 & 2.8 & 67 & 29.4 & 52 & -51.4 & 49 & -23.2 & 43 & -41.1 & 31 & -63.2 & 235 & -0.9 & 119 & -12.4 \\
\hline & 隈 & 2010 & 20,081 & & 66 & & 34 & & 53 & & 33 & & 14 & & 217 & & 106 & \\
\hline & 東 & 1990 & 9,723 & & 18 & & 38 & & 31 & & 10 & & 20 & & 49 & & 58 & \\
\hline & 比 & 2000 & 11,240 & 34.8 & 16 & 22.2 & 19 & -21.1 & 14 & -38.7 & 7 & -30.0 & 11 & -10.0 & 36 & -12.2 & 40 & 55.2 \\
\hline & 恵 & 2010 & 13,102 & & 22 & & 30 & & 19 & & 7 & & 18 & & 43 & & 90 & \\
\hline & & 1990 & 15,884 & & 31 & & 13 & & 47 & & 73 & & 22 & & 53 & & 61 & \\
\hline & 言 & 2000 & 16,551 & 13.9 & 27 & -19.4 & 11 & 15.4 & 48 & -29.8 & 49 & -69.9 & 20 & -54.5 & 50 & -26.4 & 60 & -32.8 \\
\hline & & 2010 & 18,088 & & 25 & & 15 & & 33 & & 22 & & 10 & & 39 & & 41 & \\
\hline
\end{tabular}

ここで，使われている記号を次のように定義する.

$d_{A B B}$ : A 業種の店舗 $\mathrm{i}$ から $\mathrm{B}$ 業種の最近接店舗までの直線距離,

$d_{B A d}: \mathrm{B}$ 業種の店舗 $\mathrm{j}$ から $\mathrm{A}$ 業種の最近接店舗までの直線距離,

$N_{A}: \mathrm{A}$ 業種の店舖総数,

$N_{B}:$ B 業種の店舗総数,

$N: N_{A}+N_{B}$ である.

また, $r_{E}^{\prime}$ はポアソン分布に従う場合の理論上の $\mathrm{A}$ 業種の店舗と $\mathrm{B}$ 業種の店舗の最近接平均直線距離であり，次のように定義される.

$$
r_{E}^{\prime}=\frac{n_{A}}{2} \sqrt{N_{B} / A}+\frac{n_{B}}{2} \sqrt{N_{A} / A}
$$

ただし， $n_{A}$ は店舗の総数に対する $\mathrm{A}$ 業種の店 数の割合, $n_{B}$ は同じく, B 業種の店数の割合, $\mathrm{A}$ は対象地域の面積である.

算出された $R^{\prime}$ 値によって, 業種間の分布対 応パターンを判定される. $R^{\prime}>1$ のときはラン ダムあるいは回避パターンに近く, $R^{\prime}<1$ のと きは集積パターンに近いものとみなされる.

ここでは, 2010 年の店舗立地データを用い て, R’值を算出した，表 7 に示すように，まず 同業種閒の值（表中対角線上の数字）について
みると，食堂系 (0.451), サービス系 (0.594), 文化用品系 (0.633)， 食料品系 $(0.675)$ と比較的に低い值となっていることから，この 4 業種において, 同業種の店舗は集積して立地する傾向にあり，競合 関係が薄い，また，スーパー系の値は $0.827 て ゙ ， 1$ を超えていない ものの，他業種に比べて高い值となっているため，スーパー系同士 の店舖は，ランダムあるいは回避的に立地する傾向があると考えら れる。

次いで，業種間のパターンについてみると，最も特徵があるのは サービス系である. 表 7 に示すように，サービス系とほかの業種間 の值は全て 0.867 以上で 1 に近く，地域に万遍なくランダムに分布 していると考えられる.つまり, サービス系同士の店舖が集積し，

表7 業種間の分布パターン

\begin{tabular}{l|ccccccc}
\hline & 医療系 & スーパー系 & 食料品系 & 身の回り品系 & 文化用品系 & 食堂系 & サービス系 \\
\hline 医療系 & 0.761 & & & & & & \\
スーパー系 & 0.736 & 0.827 & & & & & \\
食料品系 & 0.840 & 0.819 & 0.675 & & & & \\
身の回り品系 & 0.748 & 0.666 & 0.649 & 0.724 & & & \\
文化用品系 & 0.842 & 0.780 & 0.651 & 0.752 & 0.633 & & \\
食堂系 & 0.770 & 0.748 & 0.710 & 0.631 & 0.791 & 0.451 & \\
サービス系 & 0.960 & 0.867 & 1.000 & 0.900 & 0.977 & 0.896 & 0.594 \\
\hline
\end{tabular}


顧客利用の利便性を図りながら，地域全体に分布していると言える.

また, 食料品系についてみると, 身の回り品系, 文化用品系との 值は 0.65 前後で, 食料品同士のみならず, 上記 2 業種と店舗とも集 積して立地する傾向がある. 4.2 節で述べたように, ほとんどの地 域において食料品系の店舗が隇少していることを考えると, 食料品 系の店舗にとっては, 他業種の店舗と近接して立地することが重要 であると推測できる.

上述以外の業種間においては, $R^{\prime}$ はほぼ $0.7 \sim 0.8$ 前後に分布し ており, 特徵的なものはなく, 基本的に競合関係もなく, 他業種店 舗との集積による集客の必要もないと考えられる. 4.2 節で述べた ように医療系の店舗が多くの地域において増加したにも関わらず, 同業種あるいは他業種店舗との近接立地は見られないことから，医 療系において，この傾向がより強いといえる.

\section{5. おわりに}

1990 年代以降の規制緩和に伴う大規模商業施設の郊外などへの出店 によって，中心市街地の商業空洞化が大きな社会問題となっていた. 地 方小都市のみならず, 福岡市のような地方中枢都市でも少なからずその 影響を受けていると言われている. このような状況に加えて, 近年環境 問題に対する意識が高まる中，鉄道駅を中心とした環境にやさしいまちづ くりが推進されている. 本研究は,このような社会的背景を踏まえながら, 福岡市を事例に小規模鉄道駅の周辺地域における小売店舗の立地傾向 及びその業種間の立地パターンを明らかにしようとするものであり, 具体 的には, 1990 年, 2000 年, 2010 年の 3 調查時点の店舗, 業種の分布 実態および経年変化を把握すると同時に, 人口と乗降数との関係を分析 し, さらに, 最近隣尺度と最近隣空間的随伴尺度の指標を用いて, 小売 店舗の立地パターン及び業種別の間の分布対応パターンを明らかにして いる. ここで，既往研究の結果及び鉄道駅周辺の店舗立地メカニズムに 関する考察を含めて, 本研究で得られた新たな主な知見を次のようにまと めてみる.

まず，中心市街地における鉄道駅周辺の商業衰退は，これまでの研究 報告などの中で既に指摘されている. 本研究は日常的な買い物の場として とらえ, 乗降者数 2 万人 / 日前後の小規模鉄道駅の周辺地域に着目した. その結果, 調查対象駅の周辺人口が 1990 ～ 2010 年までほとんどの駅に おいて増加傾向にあるのに対して, 小売店舗の減少傾向が続いているこ とを確認できた. このような状況の中で, 医療系及びサービス系の店舗 がほとんどの対象駅周辺地域において増加していることがはじめて明らか となった. これは高齢化社会の進行に伴う現象であるとすれば，今後の まちづくり活動の中で重視されたい.

一方, 郊外等の大型商業施設と競合関係にある業種, つまり食料品系, 身の回り品系, 文化用品系の店舗減少が顕著であり, 駅周辺全体の店舗 減少に大きく影響しているといえる. このような状況中で，1990 年より店 舗が十数パーセント以上を増加した 3 駅の中で，福工大前と九産大前の 2 駅は大学キャンパスの付近に立地していることが注目されたい.つまり, 大学等の教育施設は地域環境に大きく影響していることは, ここでもあ らためて確認された.

さらに，店舗の立地パターンを分析した結果では，全体店舗数が減少 する状況の中で, 近年, 駅周辺の店舗がやや集積分布の傾向があると指 摘した. また，業種ごと及び業種間の店舗立地パターンについて，サー ビス系の店舗は同業種及び他業種との競合関係になく，地域全体にラン
ダムに分布していることを明らかにした.

以上のことを踏まえて，今後の鉄道駅を中心としたまちづくりの推進， 及び鉄道駅時代の利便性を向上させるために, まず食料品系, 身の回り 品系，文化用品系の店舗減少傾向を改善し，乙して近年医療系及びサ一 ビス系店舗の増加現象を考慮して，業種閒の立地傾向及び競合関係を精 査しながら総合的に店舗の出店誘致策や配置計画等を立案する必要があ ると考えられる. これを今後の課題としたい.

\section{参考文献}

1）趙世晨, 萩島哲, 出口敦, 有馬隆文, 佐谷宣昭 : 福岡市における商業施設の立 地に関する一考察，日本建築学会技術報告集，第 10 号，pp. 245-250，2000.6

2) 金漢洙, 岡田光正, 柏原士郎, 吉村英祐, 横田隆司 : 土地区画整理により開発 されたニュータウンにおける地域施設発生の予測方法について二ニータウンに おける地域施設の供給計画に関する研究一, 日本建築学会計画系論文報告集, 第 407 号, pp.97-105, 1990.1

3) 趙世晨, 萩島哲 : 商店街における自転車来街者の経路選択に関する研究, 日本 都市計画学会学術研究論文集，第 36 回，pp.901-906，2001.6

4) 佐谷宣昭, 内田晃, 趙世晨, 萩島哲 : ショッピングセンターの業種の組み合わ せと立地動向に関する研究，日本建築学会計画系論文集，第 531 号, pp. 163$170,2000.5$

5) 浅野純一郎 : 地方中核都市における自治体独自の大規模商業施設立地調整方策 の運用実態と課題に関する研究 - 金沢市と長野市の事例比較から-, 日本建築 学会計画系論文集, 第 73 巻, 第 624 号, pp. 393-400, 2008.2

6) 小林剛士，鵃心治，石村壽浩: 線引き制度運用からみた地方都市の商業施 設立地動向, 日本建築学会計画系論文集, 第 73 巻, 第 626 号, pp.811-818, 2008.4

7）姥浦道生，小泉秀樹，大方潤一郎 : 自治体レベルにおける大規模小売店舗開発 の立地コントロールの基準とその運用に関する研究-ドイツ・ノルトラインーヴェ ストファーレン (NRW) 州・ドルトムント市を事例に-, 第 37 回日本都市計画学会 学術論文集, pp.811-816, 2002.10

8) 姥浦道生 : 自治体レベルの大型商業施設の立地コントロールの効果と課題に関 する研究 - 京都市まちづくり条例を事例として-, 日本都市計画学会, 都市計画 論文集，No39-3，pp.73-78，2004.10

9）浅野純一郎，瀬口哲夫 : 幹線道路沿道に集積する商業施設の立地構造に関する 基礎的研究，第 30 回日本都市計画学会学術研究論文集，pp.169-174，1995.10

10）浅野純一郎：地方都市中心市街地における大規模商業施設の閉店や郊外移 転の実態とその後利用・跡地利用の方向性 - 北陸甲信越地方の地方自治体担 当部局への調查から-, 日本建築学会計画系論文集, 第 557 号, pp.257-264, 2007.7

11）角谷弘喜, 安藤元夫 : 商業施設立地の沿道化・沿道遠隔化過程に関する研究, 日本建築学会計画系論文報告集，第 446 号，pp.119-129，1993.4

12）山岸純一，久保田尚 : 沿道型商業施設の立地移動に関する研究，第 34 回日本 都市計画学会学術論文集, pp.943-948, 1999.10

13）木多彩子, 柏原士郎, 吉村英祐, 横田隆司, 阪田弘一, 片岡正和 : ショッピン グセンター周辺における地域施設分布実態と発生影響要因について一核型施設の 周辺地域における地域施設の発生予測に関する研究一, 日本建築学会計画系論 文集，第 475 号，pp.95-102，1995.9

14）木多彩子，柏原士郎，吉村英祐，横田隆司，阪田弘一 : ショッピングセンター の主要出入口と最寄駅の位置がその周辺の地域施設発生に及ぼす影響について 一核型施設の周辺地域における地域施設の発生予測に関する研究一，日本建築 学会計画系論文集, 第 495 号, pp.101-107, 1997.5

15）李明権，柏原士郎，吉村英祐，横田隆司 : 鉄道駅周辺地域における地域施設 の分布実態とその経年変化について，日本建築学会計画系論文集，第 455 号， pp.77-86, 1994.1

16）李明権，柏原士郎, 吉村英祐, 横田隆司, 阪田弘一 : 鉄道駅周辺地域におけ る地域施設発生の予測手法について一大規模都市施設の周辺における地域施設 の発生予測に関する研究，日本建築学会計画系論文集，第 477 号, pp.71-79, 1995.11

17) 株式会社ゼンリン: ゼンリン住宅地図 (福岡市 1990, 2000, 2010)

18）福岡商工会議所 : 福岡市における商店街の実態調査報告書, 1998

19）杉浦芳夫編 : 地理空閒分析, 朝倉書店, 2003 